\title{
Have you ever seen a pathologist with acne vulgaris?
}

\author{
Siz hiç akne vulgarisi olan patolog gördünüz mü?
}

Keywords: Acne vulgaris, formaldehyde, pathology

Anahtar Kelimeler: Akne vulgaris, formaldehit, patoloji

\section{To Editor,}

Acne vulgaris (AV) is an inflammatory disease of pilosebaceous unit ocuring frequently in adolescences. The most important factors association with the pathogenesis of AV are folicular keratinization, androgens, increased sebum production and Propionibacterium acnes. In addition, emotional stress, drugs, cosmetics, and mechanical factors may trigger it. AV has such findings as comedon, papulopustule, nodule and cyst. Various treatment options modifying its etiopathogenic processes acording to its severity are present.

Formalin is $40 \%$ diluted solition of formaldehyde. In pathology, most commonly $10 \%$ formalin (i.e. $4 \%$ formaldehyde) is used for the fixation of micro-anotomy of the living tissue 1 . In this latter, an interesting experience of an pathology resident whose acne complaints improved after short term exposure to formaldehyde vapor is shared.

A female colleague with moderate papulopustuler AV on the face at the age of 25 started pathology residency three weeks ago and complete regression of acne complaints occurred one week ago. She had no known additional disease or chronic drug use. She did not use any treatment or cosmetic products for her acne within the last one month and there was no change in her emotional stress. She was working on macroscopic biopsy samples transferred in formalin solution during the last two weeks. Contact with formalin solution was made using gloves and protective suits. There was no contact of solution with the face, although necessary precautions were taken for adequate ventilation of the environment, smell of formaldehyde was strongly noticeable felt in the room. Our colleague who continued to work in the same environment for 2 months did not repeat the acne complaint during this period. Afterwards, in the direction of our colleague's observation, it was learned that acne lesions increased in the months when the frequency of exposure to formalin decreased, and vice versa.

In fixation procedure; formalin protects the tissue from autolysis caused by active cellular enzymes or from decomponsation provide by fungi, inactivates or kills infectious agents; stabilizes tissue components ${ }^{1}$. It is important for a good fixative agent to have high penetration ability.

Approach to acne treatment is focused on its pathogenesis. The improvement in the clinical picture of our colleague after exposure to $10 \%$ formalin suggests this question: "At which stage of pathogenesis does formaldehyde exert its effect?" In the study of Eady and Cove ${ }^{2}$, investigating the role of $P$ acnes in the pathogenesis of $A V_{\text {, }}$ it has been reported that $P$. acnes killed with formalin cannot stimulate in vitro cytokines production in cultures of human keratinocytes. It is our belief that in vivo contact of formalin vapor in our colleague improved clinical symptoms of $\mathrm{AV}$ through a

Address for Correspondence/Yazışma Adresi: Çağrı Turan MD, University of Health Sciences, Ankara Health Practice and Research Center, Clinic of Skin and Venereal Diseases, Ankara, Turkey Phone.: +90 5445252504 E-mail: cagrituranmd@gmail.com

Received /Geliş Tarihi: 08.04.2018 Accepted /Kabul Tarihi: 18.06.2018 ORCID ID: orcid.org/0000-0002-6111-4314

CCopyright 2018 by Turkish Society of Dermatology and Venereology

Turkderm-Turkish Archives of Dermatology and Venereology published by Galenos Yayınevi. 
similar antibacterial mechanism. In addition, fixation with formalin has other adverse effects on cells such as changes in protein structure and breakdown of nucleic acids ${ }^{1,3}$. Therefore, the observation of Eady and Cove $^{2}$ suggests that the benefit of formalin may be due to the decrease in antigenic stimulation associated with other cellular and molecular damage which it incurs as well as its bactericidal effect.

It has been reported that acute or chronic exposure to formaline cause allergic contact dermatitis as well as irritation and peeling ${ }^{4}$. There was no irritation in the present case. It can be thought that keratolytic mechanism is also effective in the regression of the acne lesions. Due to high penetration of ability of formalin, we believe that although there was no direct contact with it, its vapor may have been adequate for clinical response.

Exposure to formalin can cause skin irritation, burning sensation of the nose and eyes, asthma attacks. In addition, recent studies have shown that formaldehyde, which is exposed to inhalation, is causally related to various malignancies, especially hematopoietic neoplasms in humans ${ }^{5}$. For this reason, it is important that the work environment is well ventilated in departments such as anatomy, pathology where occupational exposure to formalin is intense.

Despite their risks, formaldehyde is known to be used as a preservative substance in many cosmetics such as deodorants, makeup products. As far as we know, no form of formaldehyde has been reported to be used in acne treatment. In view of the information above, the use of formaldehyde in acne treatment cannot be recommended unless randomized controlled trials are carried out providing its safety. However, direct or indirect exposure to formaldehyde due to occupational and compulsory conditions can present inspirational information about the effects of formaldehyde on acne lesions.

\section{Ethics}

Informed Consent: Written and oral consent was obtained from the reported case.

Peer-review: Externally peer-reviewed.

\section{Authorship Contributions}

Surgical and Medical Practices: Ç.T., Concept: Ç.T., H.M.E., Design: Ç.T., H.M.E., Data Collection or Processing: Ç.T., N.P.Ç., Analysis or Interpretation: Ç.T., H.M.E., Literature Search: Ç.T., N.P.Ç., Writing: Ç.T.

Conflict of Interest: No conflict of interest was declared by the authors.

Financial Disclosure: The authors declared that this study has received no financial support.

\section{References}

1. Fox $\mathrm{CH}$, Johnson FB, Whiting J, Roller PP: Formaldehyde fixation. J Histochem Cytochem 1985;33:845-53.

2. Eady EA, Cove JH: Is acne an infection of blocked pilosebaceous follicles? Implications for antimicrobial treatment. Am J Clin Dermatol 2000;1:201-9.

3. Liu Y, He H, Yi S, et al.: Comparison of different methods for repairing damaged DNA from buffered and unbuffered formalin-fixed tissues. Int $J$ Legal Med 2017.

4. Suruda A: Morticians. Occupational, Industrial, and Environmental Toxicology. Ed Greenberg MI, Hamilton RJ, Phillips SD, GJ M. 2. edition. Philadelphia, Mosby 2003:274-83.

5. Kwon SC, Kim I, Song J, Park J: Does formaldehyde have a causal association with nasopharyngeal cancer and leukaemia? Ann Occup Environ Med 2018;30:5. 